\title{
Tes Toleransi Glukosa Oral (TTGO) Pasca Pemberian Suspensi Kedelai Dibanding Suspensi Tempe pada Tikus (Rattus norvegicus Galur Wistar) Diabetik
}

\author{
Masdar, $\mathrm{H}^{1}$, Hakiki, M.R ${ }^{2}$, Syahputra, M.R ${ }^{2}$, Satriasumatri, ${ }^{2}$, \\ Putri, $D^{2}$, Bunaya, $R^{2}$, Juananda, $D^{3}$ \\ ${ }^{1}$ KJF Histologi Fakultas Kedokteran Universitas Riau \\ email: huriatul.masdar@gmail.com \\ ${ }^{2}$ Program Studi Pendidikan Dokter Fakultas Kedoketeran Universitas Riau \\ ${ }^{3}$ KJF Anatomi, Fakultas Kedoketeran Universitas Riau
}

\begin{abstract}
Abstrak
Pendahuluan: Gensitein, daidzein dan glisetin merupakan isoflavon-isoflavon kedelai yang telah dikenal memiliki efek anti diabetes. Proses fermentasi dari kedelai dapat menyebabkan terbentuknya isoflavon aglikan yang memiliki bioavailabilitas lebih tinggi dari pada kedelai yang tidak difermentasi. Tujuan penelitian: mengetahui efek pemberian kedelai dan tempe (produk fermentasi kedelai) terhadap tes toleransi glukosa oral (TTGO) tikus putih diabetik. Metode: Sebanyak dua puluh ekor tikus Rattus novergicus jantan galur Wistar digunakan dalam penelitian ini dan dibagi ke dalam 4 kelompok yakni: standard, kontrol negatif, kedelai dan tempe. Diabetes melitus tipe 2 pada tikus diinduksi dengan memberikan streptozotocin $(50 \mathrm{mg} / \mathrm{kgBB}) \mathrm{dan}$ nikotinamid $(110 \mathrm{mg} / \mathrm{kgBB})$ secara intraperitoneal. Glukosa darah diperiksa dengan mengggunakan blood glucose test meter dan ditetapkan menjadi diabetes jika kadar glukosa darah $>200 \mathrm{mg} / \mathrm{dL}$. Suspensi Kedelai (200mg/kgBB/hari) dan suspensi tempe (200 mg/kg/BB/hari) diberikan dengan menggunakan sonde selama 30 hari. Hasil: Hasil penelitian menunjukkan bahwa baik glukosa darah puasa (GDP) ataupun kadar glukosa 2 jam postprandial (G2PP) kelompok kontrol negatif tetap persisten $>200 \mathrm{mg} / \mathrm{dL}$ pada hari ke-15 dan 30 (p>0.05). Pada kelompok kedelai, terdapat penurunan nilai GDP pada hari ke-15 $(\mathrm{p}<0.05)$ tetapi tidak sampai mencapai batas nilai normal, dan pada hari ke-30 nilai dari GDP $<200 \mathrm{mg} / \mathrm{dL}$ ( $\mathrm{p}<0.05$ ), namun nilai kadar dari G2PP masih tetap $>200 \mathrm{mg} / \mathrm{dL}(\mathrm{p}<0,05)$. Selain itu, pada kelompok tempe, nilai dari GDP dan G2PP mampu mencapai batas nilai normal pada hari ke-15 dan ke-30 ( $<<0,05)$. Kesimpulan: Hasil penelitian ini menunjukkan bahwa pemberian tempe lebih baik dalam mengontrol nilai glukosa darah dari pada kedelai.
\end{abstract}

Kata Kunci - Diabetes, Kedelai, Tempe, TTGO

\section{Abstract}

Introduction: Genistein, daidzein and glicytein are soybean's isoflavones which have been known having anti diabetic effect. Fermentation process of soybean can lead to formation aglycan isoflavones which have higher bioavailability than unfermented-soybean. Aims: This research was aimed to evaluate the effect of soybean and tempeh (fermented-soybean) administration to oral glucose tolerance test (OGTT) in diabetic rats. Method: Twenty male Rattus norvegicus Wistar strains were used in this experiment, divided into 4 groups: standard, negative control, soybean and tempeh group. Type 2 diabetes in rats was induced by giving streptozotocin (50 $\mathrm{mg} / \mathrm{kgBW})$ and nicotinamide $(110 \mathrm{mg} / \mathrm{kgBW})$ intraperitoneally. Blood glucose were measured by using blood glucose test meter and classified into diabetes if its level above $200 \mathrm{mg} / \mathrm{dL}$. Soybean (200 $\mathrm{mg} / \mathrm{kgBW} /$ day $)$ and tempeh (200 mg/kgBW/day) suspension were given by using gastric tube for 30 days. Results: The results showed the means of either fasting blood glucose (FBG) or 2 hours post prandial blood glucose (2hPP) of negative control were persistent above $200 \mathrm{mg} / \mathrm{dL}$ on day $15^{\text {th }}$ and $30^{\text {th }}(\mathrm{p}>0,05)$. In soybean group there was a decrease the mean of FBG on day $15^{\text {th }}(p<0.05)$ but did not reach the normal level, and on day $30^{\text {th }}$ the mean of FBG was $<200 \mathrm{mg} / \mathrm{dL}$ ( $p<0.05)$ however $2 \mathrm{hPP}$ blood glucose was still $>200 \mathrm{mg} / \mathrm{dL}(\mathrm{p}<0.05)$. Furthermore, in tempeh group, the means of either FBG or $2 \mathrm{hPP}$ blood glucose reached the normal level in day $15^{\text {th }}$ and $30^{\text {th }}(p$ $<0.05)$. Conclusion: the provision of tempeh was better in controlling blood sugar levels than soybean.

Keywords- Diabetes, Oral glucose tolerance test, Soybean, Tempeh

Health \& Medical Journal 


\section{Pendahuluan}

Diabetes melitus (DM) merupakan suatu sindroma metabolik dengan kerakteristik hiperglikemi, yang terjadi karena kelainan sekresi insulin, kerja insulin atau keduaduanya. ${ }^{1}$ Hiperglikemia adalah suatu kondisi medik yang berupa meningkatnya kadar glukosa darah dari batas normal, dengan kadar glukosa darah sewaktu >200 mg/dl atau kadar glukosa darah puasa $>126 \mathrm{mg} / \mathrm{dl}$. Gejala khas pasien yang mengalami DM adalah poliuria, polidipsia, polifagia dan ${\text { penurunan } \text { berat. }^{2}}^{2}$

World Health Organization (WHO) melaporkan bahwa terjadi peningkatan jumlah mortilitas yang disebabkan oleh DM dari 1 juta jiwa (2\%) pada tahun 2000 menjadi 1,5 juta jiwa $(2,7 \%)$ pada tahun 2012. Pada tahun 2012 diabetes melitus menduduki peringkat ke delapan dari 10 penyakit tertinggi yang menyebabkan kematian di dunia. Diabetes melitus di Indonesia pada tahun 2012 menduduki peringkat ke tiga dari 10 penyakit tertinggi yang menyebabkan kematian setelah stroke dan penyakit jantung koroner. $^{3}$ Pada penelitian yang telah dilansirkan dalam riset kesehatan dasar (RIKESDAS) terdapat adanya peningkatan kejadian diabetes melitus di Indonesia dari $1,1 \%$ pada tahun $2007,{ }^{4}$ menjadi $2,1 \%$ pada tahun $2013 .^{5}$ di tahun 2013 didapatkan sekitar $69,6 \%$ pasien DM yang belum terdiagnosis oleh dokter namun telah ditemukan gejala-gejala klinis yang khas. ${ }^{5}$

Tes toleransi glukosa oral (TTGO) dapat dilakukan pada keadaan ditemukannya gejala klinis akan tetapi pada pemeriksaan laboratorium glukosa darah puasa (GDP) atau glukosa darah sewaktu (GDS) tidak melebihi batas normal (cut off) atau sebaliknya. ${ }^{6}$ Pemeriksaan TTGO dengan cara induksi glukosa secara oral mampu menstimulasi sekresi insulin sehingga bisa mengatur kadar glukosa darah ke dalam rentang yang normal. Penelitian yang dilakukan Stumvoll et al menunjukkan bahwa TTGO dapat mengevaluasi fungsi sel $\beta$-pankreas dan sensitivitas jaringan terhadap insulin. ${ }^{7}$ Selain itu, TTGO juga dapat menilai keadaan glukosa darah puasa terganggu (GDPT) dengan nilai $<140 \mathrm{mg} / \mathrm{dL}$, toleransi glukosa terganggu (TGT) dengan kadar glukosa 140-199 mg/dL. Pasien dinyatakan mengidap penyakit DM apabila kadar glukosa darah pada pemeriksaan TTGO $>200 \mathrm{mg} / \mathrm{dL}^{2}$

Hiperglikemia kronik yang terpadat pada pasien diabetes melitus dapat meningkatkan pembentukan radikal bebas melalui stimulasi terhadap pembentukan reactive oxygen species (ROS) dari fosforilasi oksidatif, autooksidasi glukosa, oksidasi NADPH, lipooksigenase, cytochrome P450 monooxygenase dan nitric oxide synthase (NOS), selain itu, terdapat adanya peningkatan kadar lipid peroksidase yang berperan besar dalam perkembangan inflamasi terhadap pembuluh darah yang dapat memicu komplikasi pada sistem kardiovaskuler. Lipid peroksidase juga diketahui mampu menggangu sekresi insulin dengan merusak mitokondria sel $\beta$ pankreas. ${ }^{8,9}$ Selain peningkatan lipid peroksidase, kondisi diabetes menyebabkan penurunan kadar glutathion dan superoxide dismutase (SOD). ${ }^{9,10}$ SOD dan glutathion adalah antioksidan endogen yang berfungsi untuk menetralisir oksidan yang terbentuk. Hal ini menyebabkan peningkatan terhadap asupan gizi yang adekuat sebagai sumber antioksidan eksogen untuk memenuhi kebutuhan antioksidan didalam tubuh terutama pada pasien diabetes melitus.

Kacangan-kacangan khususnya kedelai merupakan salah satu sumber antioksidan melalui kandungan isoflavonnya. Isoflavon merupakan turunan dari golongan flavonoid yang bermanfaat sebagai antioksidan eksogen. ${ }^{11}$ Dengan pemberian asupan diet isoflavon pada tikus DM di dapatkan meningkatnya kadar enzim superoxide dismutase, catalase, dan glutathione 
peroxidase dibandingkan pada tikus DM yang tanpa diberi perlakuan. ${ }^{12}$. Penelitian yang dilakukan oleh Suarsana et al tahun 2012 menunjukkan bahwa pemberian isoflavon pada dosis $1,5-2 \mathrm{mg} / 200$ gram berat badan tikus dapat memicu peningkatan metabolisme glukosa di dalam tubuh melalui peningkatan pemasukkan glukosa kedalam sel. ${ }^{13}$ Diduga bahwa kandungan genistein dalam isoflavon kedelai mampu memperbaiki kadar glukosa darah pada diabetes melitus dengan cara melindungi sel $\beta$-pankreas dari apoptosis dan mempertahankan fungsi sel $\beta$-pangkreas. ${ }^{14}$

Salah satu olahan kedelai yang sering digunakan oleh masyarakat adalah tempe. Tempe merupakan makanan tradisional Indonesia yang berasal dari fermentasi kedelai oleh Rhizopus $s p .{ }^{15}$ Proses fermentasi ini menyebabkan isoflavon aglikon yang merupakan isoflavon yang penting meningkat secara signifkan. ${ }^{16}$ Isoflavon aglikon diketahui memiliki biovaibilitas yang lebih tinggi dibandingkan isoflavon lainnya yakni glikosida. Hal ini disebabkan isoflavon aglikon dapat langsung diabsorpsi secara langsung oleh sel usus sedangkan isoflavon glikosida harus dihidrolisis terlebih oleh enzim $\beta$-glucosidase usus sebelum di absorbsi dan di bawa ke sirkulasi perifer. ${ }^{17}$

Oleh karena itu perlu diteliti lebih lanjut perbandingan efek pemberian suspensi kedelai dan suspensi tempe terhadap kadar glukosa darah tikus diabetes.

\section{Metode Penelitian}

Penelitian ini telah mendapatkan persetujuan etik penelitian yang diterbitkan oleh Unit Etik Penelitian Kedokteran dan Kesehatan Fakultas Kedokteran Universitas Riau. Tempe dan kedelai yang digunakan dalam penelitian ini didapatkan dari produsen rumah tempe yang telah dapat izin dari Depertemen Kesehatan (15A/STP/06215/VII/1987). Tempe dan kedelai dibuat dalam bentuk suspensi.
Jenis penelitian ini bersifat eksperimental dengan menggunakan rancangan PretestPostest with Control Group Design. Penelitian ini dilakukan di laboratorium hewan coba Fakultas Kedokteran Universitas Riau dengan menggunakan 24 ekor tikus Rattus novergicus galur Wistar jantan yang didapatkan dari Fakultas Kedokteran Universitas Sumatera Utara dengan berat badan 150-220 gram. Dibagi menjadi 4 kelompok. K 1 (normal + diet standar), K2 (diabetik + diet standar), K3 (diabetik + diet kedelai), dan K4 (diabetik + diet tempe). Untuk menjadikan tikus diabetik, tikus percobaan di injeksi Streptozotocin (STZ) dan Nikotinamid (NA) dilakukan secara Intra Peritoneal (IP) dengan dosis STZ 50 $\mathrm{mg} / \mathrm{KgBB}$ dan NA $110 \mathrm{mg} / \mathrm{KgBB}$. Kadar glukosa darah diperiksa 3 hari pasca injeksi dengan pengukuran menggunakan blood glucose test meter, darah diambil dari ekor tikus dan tikus yang dinyatakan diabetes apabila kadar glukosa darah > $200 \mathrm{mg} / \mathrm{dl}$. Tikus yang telah dikatakan DM akan diberikan perlakuan kedelai dan tempe sebanyak $200 \mathrm{mg} / \mathrm{KgBB}$ selama 30 hari. Prosedur pelaksanaan TTGO, tikus dipuasakan terlebih dahulu selama 12 jam dan kemudian diperiksa GDP selanjutnya dilakukan dengan memberikan glukosa sebanyak 1 gram $/ \mathrm{KgBB}$ kemudian glukosa darah diperiksa 2 jam post prandial (G2PP) dan dilakukan pada hari ke 0,15 dan 30 pasca dinyatakan tikus telah diabetik. Data yang diperoleh akan dianalisis dengan uji statistik mengunakan repeated Anova dan One way Anova.

\section{HASIL}

Pada penelitian ini, dari 18 ekor tikus yang telah di injeksi STZ dan NA, hanya 11 ekor tikus yang dapat dikatakan diabetes dengan kadar GDP dan G2PP >200 mg/dl. Dari 11 ekor tikus diabetik maka dibagi berdasarkan kelompok secara acak yaitu 3 ekor tikus pada kelompok tikus $\mathrm{K} 2$, 4 ekor tikus pada kelompok K3 dan 4 ekor tikus pada kelompok K4. Kadar glukosa darah pada 
tikus akan dievaluasi pada hari ke 0,15 dan 30 dengan metode pemeriksaan TTGO dicantumkan pada Tabel 1.

TABEL 1. RATA-RATA BERAT BADAN, GDP, DAN G2PP

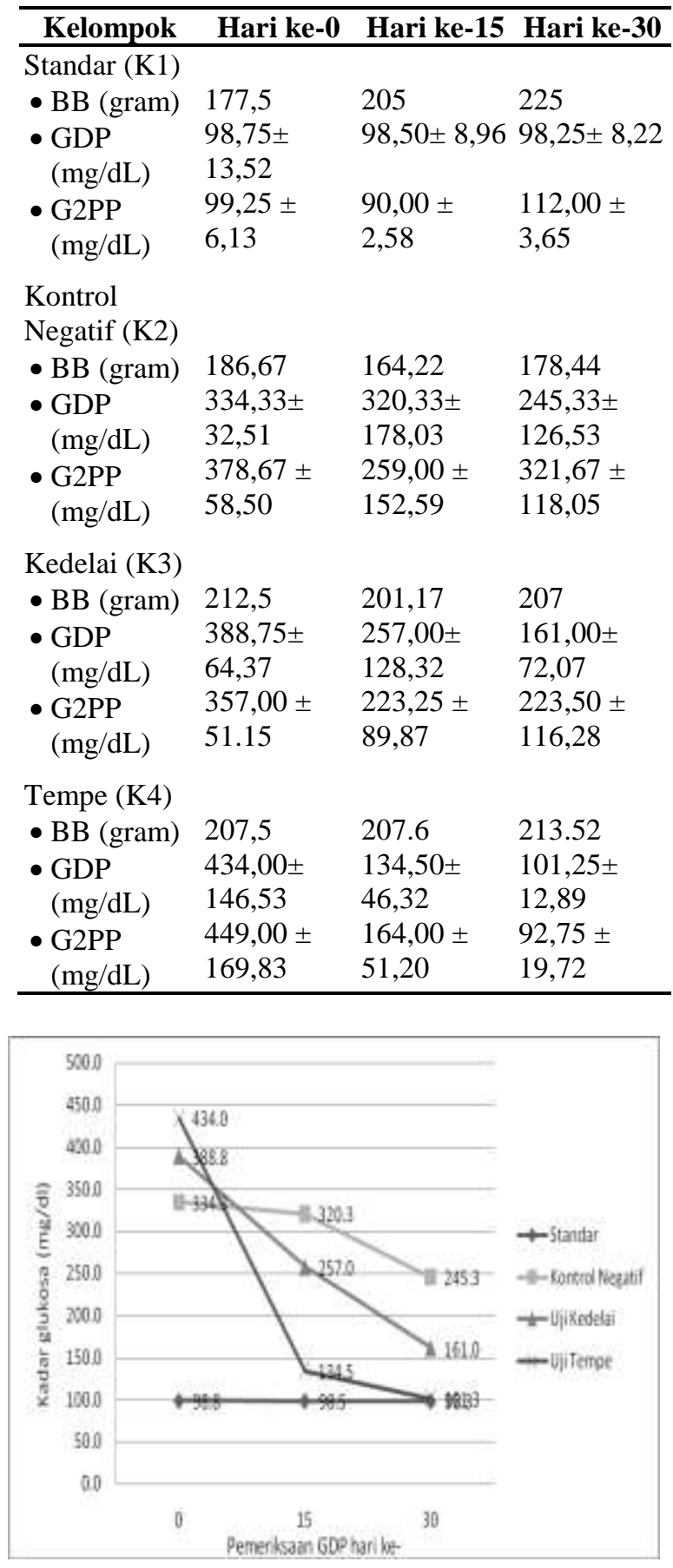

GAMBAR 1.1 RATA-RATA KADAR GLUKOSA DARAH PUASA (GDP)

Dari Gambar 1.1 dan Gambar 1.2 dapat dilihat bahwa semua kelompok yang diinjeksi STZ dan NA (K2, K3 dan K4) didapatkan adanya peningkatan kadar GDP dan G2PP yaitu >200 mg/dL. Kelompok K2 setalah 15 dan 30 hari perlakuan tidak adanya penurunan kadar glukosa darah baik berupa GDP ataupun G2PP yang bermakna ( $p>0,05)$. Kelompok K3 setelah 15 hari perlakuan terdapat penurunan yang bermakna kadar GDP dan G2PP dengan nilai $\mathrm{p}<0,05$, di hari ke 30 pada pemeriksaan GDP terdapat penurunan kadar glukosa darah yang bermakna $(\mathrm{p}<0,05)$ namun masih di atas kelompok K1 (>100 mg/dL). Akan tetapi, pada pemeriksaan G2PP tidak ada penurunan kadar glukosa darah yang bermakna ( $>0,05)$. Sedangkan kelompok K4 kadar GDP dan G2PP hari ke 15 dan 30 setalah diberikan perlakuan terdapat penurunan yang bermakna $(p<0,05)$ dengan di hari 30 kadar glukosa telah mencapai normal $(\leq 100$ $\mathrm{mg} / \mathrm{dL}$ ) atau di bawah kelompok K1.

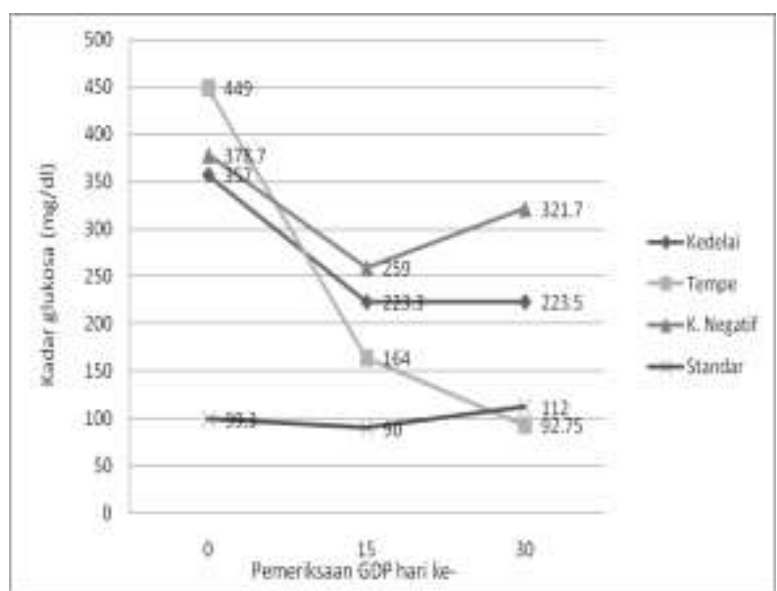

GAMBAR 1.2 RATA-RATA KADAR GLUKOSA 2 JAM POSTPRANDIAL (G2PP)

Hasil pemeriksaan GDP dan G2PP di hari ke 0, 15 dan 30 diuji secara statistik dengan menggunakan uji One way Anova untuk menilai perbandingan kadar gluosa darah setiap kelompok yang diberikan perlakuan.

\section{PERbandingan Kadar GDP DAN G2PP TIAP KELOMPOK PADA HARI 0 (TO)}

Uji statistik normalitas data menggunakan Shapiro-Wilk didapatkan data GDP dan G2PP menunjukkan $p>0,05$ sehingga dapat dikatakan bahwa data tersebut terdistribusi 
normal. Selanjutnya dilakukan uji hipotesis menggunakan parametrik uji Annova dengan hasil didapatkan $\mathrm{p}<0,05$ sehingga didapatkan bahwa Ha diterima dan $\mathrm{HO}$ ditolak, dengan pengertian bahwa terdapat perbedaan yang bermakna kadar GDP dan G2PP setiap kelompok pada hari 0. Setelah itu dilanjutkan pada uji Tukey didapatkah bahwa perbedaan yang bermakna terletak pada kelompok standar (K1) dengan kelompok yang diinjeksi STZ dan NA (K2,K3,dan K4), sehingga dapat disimpulkan bahwa dengan pemberian injeksi STZ dan NA dapat menyebabkan peningkatan kadar glukosa darah baik berupa GDP ataupun G2PP.

\section{PERbandingan Kadar GDP DAN G2PP TIAP KELOMPOK PADA HARI 15 (T15)}

Uji normalitas data GDP dan G2PP semua kelompok menggunakan uji Shapiro-Wilk menunjukkan distribusi normal $(\mathrm{p}>0,05)$. Sedangkan pada uji Annova didapatkan tidak adanya perbedaan secara bermakna kadar GDP dan G2PP setiap kelompok.

\section{Perbandingan Kadar GDP dan G2PP TiaP KELOMPOK PADA HARI 30 (T30)}

Setelah 30 hari diberikan perlakuan, data rata-rata kadar GDP dan G2PP yang diperoleh dilakukan uji statistik. Pada uji normalitas menggunakan Shapiro-Wilk didapatkan data terdistribusi normal dengan nilai $\mathrm{p}>0,05$. Uji hipotesis dengan menggunakan parametrik uji Annova menunjukkan adanya perbedaan yang bermakna kadar glukosa darah baik berupa GDP ataupun G2PP pada setiap kelompok $(\mathrm{p}<0,05)$. Dan pada uji Tukey didapatkan adanya penurunan kadar GDP dan G2PP yang signifikan pada tikus kelompok Tempe (K4) dibandingkan pada kelompok kontrol negatif (K1) dengan nilai $\mathrm{p}<0,05$.

\section{Pembahasan}

Meningkatnya prevalensi penyakit diabetes melitus berhubungan erat dengan pola kehidupan masyarakat. Pola kehidupan sedentari yang berkembang ditengah kehidupan masyarakat, konsumsi makanan tinggi kalori dan obesitas menjadi faktor meningkatnya insidensi pengidap diabetes melitus. ${ }^{18}$ Salah satu upaya yang bisa dilakukan untuk menurunkan kadar glukosa darah adalah dengan memperhatikan faktor asupan gizi. Kedelai yang merupakan salah satu komoditi pangan penting di Indonesia juga dikenal memilki kadungan gizi yang tinggi. Kedelai dikenal mengandung isoflavon yang merupakan antioksidan eksogen dan turunan dari flavonoid yang bermanfaat dalam menurunkan resiko penyakit kardiovaskular dan kanker. ${ }^{11}$ Senyawa antioksidan mampu memberikan efek menguntungkan terhadap fungsi sel $\beta$ pankreas pasien DM. Antioksidan mampu mencegah atau menunda disfungsi sel $\beta$ pankreas pasien DM dengan memberikan perlindungan terhadap oksidasi sel $\beta$ pankreas. ${ }^{19}$

Terdapat 12 isomer isoflavon dalam kedelai, 3 isomer dalam bentuk aglikan yaitu genistein, daidzein dan glycitein, serta 9 isomer dalam bentuk glikosida yaitu daidzin, genistin dan glisitin; 6-Oacetyldaidzin, -genistin, -glycitin; 6"-Omalonyldaidzin, -genistin, -glycitin. Isoflavon utama pada kedelai adalah dalam bentuk glikosida yang terdiri dari $64 \%$ genistin, $23 \%$ daidzin dan $13 \%$ glisitin. $^{20}$ Dalam penelitian ini, pada hari ke-15 setelah diberikan suspensi kedelai terdapat penurunan kadar GDP dan G2PP secara bermakna namun pada hari ke 30 hanya pada pemeriksaan GDP yang terjadi penurunan kadar glukosa darah yang berarti meskipun masih berada diatas kelompok standar. Sehingga penurunan kadar glukosa darah ini diduga kandungan isoflavon didalam kedelai mampu menurunkan kadar glukosa darah, hal ini sesuai dengan pada penelitian Suarsana et al tahun 2012 mengatakan bahwa dengan pemberian isoflavon pada dosis $1,5-2 \mathrm{mg} / 200$ gram berat badan tikus dapat memicu peningkatan metabolisme 
glukosa di dalam tubuh melalui peningkatan pemasukkan glukosa kedalam sel. ${ }^{13}$ Isoflavon dapat memperbaiki kerusakan sel $\beta$-pankreas sehingga terjadinya peningkatan sekresi insulin yang menyebabkan penurunan kadar glukosa darah, ${ }^{14,21}$ selain itu isoflavon dapat meningkatkan antioksidan endogen berupa glutathion dan berefek dalam menurunkan radikal bebas didalam darah untuk mencegah komplikasi yang terjadi pada penyakit diabetes. ${ }^{21}$

Tempe merupakan salah satu makanan tradisional Indonesia yang berasal dari kedelai yang difermentasi dengan menggunakan ragi Rhizopus sp. ${ }^{15}$ Pada penelitian ini, dengan pemberian suspensi tempe pada tikus diabetik dapat menurunkan kadar glukosa darah baik berupa GDP ataupun G2PP yang signifikan pada hari ke15 dan 30 pasca perlakuan.

Penurunan kadar glukosa darah dapat mencapai batas normal atau berada di bawah kelompok standar yang terjadi pada hari ke 30 pada kelompok tempe, dibandingkan kedelai yang juga terdapat penurunan kadar glukosa darah namun tidak mencapai normal atau masih berada diatas kelompok standar. Hal ini diduga karena adanya perubahan struktur isoflavon akibat proses fermentasi yang menyebabkan isoflavon lebih cendrung dalam bentuk aglikan yaitu genistein, daidzein dan glycitein. $^{20}$ isoflavon lebih dominan dalam bentuk bebas/aglikan karena aktifitas mikrobanya. Bioavaibilitas isoflavon aglikon lebih tinggi daripada isoflavon glikosida karena sifatnya yang langsung diserap oleh usus. Isoflavon glikosida bersifat hidrofilik dan memiliki berat molekul yang besar sehingga membutuhkan proses hidrolisis oleh enzim $\beta$-glukosidase di usus sebelum diabsorbsi, proses ini akan mengkonversi isoflavon glikosida menjadi isoflavon aglikan sehingga daya absorbsinya meningkat. ${ }^{17}$ Dalam berbagai olahan fermentasi kedelai, didapatkan isoflavon tempe lebih tinggi dari pada olahan yang lainnya. ${ }^{22}$

\section{KESIMPULAN DAN SARAN}

Dalam penelitian ini dapat disimpulkan bahwa dengan pemberian suspensi kedelai dan suspensi tempe dapat menurunkan kadar glukosa darah pada tikus diabetik. Namun, pemberian tempe dapat menurunkan kadar glukosa darah yang signifikan sehingga dapat mencapai batas normal dibandingkan pada pemberian kedelai. Mengingat adanya perubahan kandungan gizi selama proses fermentasi kedelai, sehingga dapat dilakukan penelitian lebih lanjut untuk menilai kandungan dan manfaat olahan makanan fermentasi lainnya.

\section{Daftar Pustaka}

[1] American Diabetes Association. Diagnosis and classification of diabetes mellitus. 2014 Jan;37:81-90.

[2] Perkumpulan Endokrinologi Indonesia (PERKENI). Pengelolaan Dan Pencegahan Diabetes Melitus Tipe 2 Di Indonesia 2015. PB PERKENI. 2015 Jul.6-14.

[3] World Health Organization (WHO). Global Report on Diabetes.2015.

[4] Badan Penelitian dan Pengembangan Kesehatan. Riset kesehatan dasar (RISKESDAS) 2007. Lap Nas 2007. 2008.

[5] Badan Penelitian dan Pengembangan Kesehatan. Riset kesehatan dasar (RISKESDAS) 2013. Lap Nas 2013. 2013.

[6] Purnamasari D. Diagnosis dan klasifikasi diabetes melitus. In: Siti S, Alwi I, Sudoyo AW, K MS, Setiyohadi B, Syam AF, eds. Buku Ajar Ilmu Penyakit Dalam. VI. Jakarta: Interna Puplishing; 2015:2325-2329.

[7] Stumvoll M, Mitrakou A, Pimenta W, Jenssen T, YKI-JÄRVINEN H, Haeften T van. Use of $t$ ce Test to Assess Insulin Release and Insulin Sensitivity. Diabetes Care. 2000 Mar;23(3):295301.

[8] Valko M, Leibfritz D, Moncol J, Cronin MTD, Mazur M, Telser J. Free radicals and antioxidants in normal physiological functions and human disease. Int $\mathbf{J}$ Biochem Cell Biol. 2006 Agus; 39:44-84.

[9] Kesavulu MM, Rao BK, Giri R, Vijaya J. Lipid peroxidation and antioxidant enzyme status in Type 2 diabetics with coronary heart disease. Diabetes Res Clin Prac. 2001 Feb 6;53:33-39.

[10] Kumawat M, Sharma TK, Singh I, et al. Antioxidant Enzymes and Lipid Peroxidation in Type 2 Diabetes Mellitus Patients with and without Nephropathy. North American Journal of Medical Sciences. 2013 Mar ;5(3). 213-9. 
[11] Ivey KL, Hodgson JM, Croft KD, Lewis JR, Prince RL. Flavonoid intake and all-cause mortality. Am J Clin Nutr. 2015; 101 :1012-20.

[12] Lee J. Effects of soy protein and genistein on blood glucose, antioxidant enzyme activities , and lipid profile in streptozotocin-induced diabetic rats. Life Sciences. 2006;79:1578-84.

[13] Suarsana IN, Widyastuti S, Priosoeryanto BP. Ketersediaan hayati isoflavon dalam plasma dan pengaruhnya terhadap nilai biokimia darah pada tikus hiperglikemia. Veteriner. 2012;13(1):8691.

[14] El-Kordy EA, Alshahrani AM. Effect of genistein, a natural soy isoflavone, on pancreatic $\beta$-cells of streptozotocin-induced diabetic rats: Histological and immunohistochemical study. J Microsc Ultrastruct. 2015;3(3):108-19.

[15] Muchtadi D. Kedelai Komponen Untuk Kesehatan. Bogor: Alfabeta; 2010.

[16] Haron H, Azlan A, A I. Daidzein and genestein contents in tempeh and selected soy products. Food chemestry. 2009 Aug; 115: 1350-6.

[17] Izumi T, Piskula MK, Osawa S, et al. Soy Isoflavone Aglycones Are Absorbed Faster and in Higher Amounts than Their Glucosides in Humans.J Nutr. 2000 Feb;130:1695-1699.

[18] Suyono S. Diabetes melitus di Indonesia. In: Siti S, Alwi I, Sudoyo AW, K MS, Setiyohadi B, Syam AF, eds. Buku Ajar Ilmu Penyakit Dalam. VI. Jakarta: Interna Puplishing; 2015:2317.

[19] Ariviani S, Handajani S, Affandi DR, Listyaningsih E. Potensi minuman bubuk kedelai (var. Galunggung) sebagai minuman fungsional : sifat fisikokimia, efek hipoglikemik dan hipokolesterolemik serta status antioksidan. J Gizi Klin Indones. 2012;8(4):158-165.

[20] Wang H, Murphy P a. Isoflavone Content in Commercial Soybean Foods. J Agric Food Chem. 1994;42(8):1666-73.

[21] Lu M, Wang R, Song X, et al. Dietary soy isoflavones increase insulin secretion and prevent the development of diabetic cataracts in streptozotocin-induced diabetic rats. Nutri Research. 2008; 28: 464-71.

[22] Sapbamrer R, Visavarungroj N, Suttajit M. Effects of dietary traditional fermented soybean on reproductive hormones, lipids, and glucose among postmenopausal women in northern. Thailand. Asia Pac J Clin Nutr. 2013; 22(2):222-8 